\title{
地形的背景からみた岩手県北上山地における 平成28年 8 月台風第10号豪雨の土砂移動 \\ Geomorphological background of sediment movements during Typhoon Lionrock in the central Kitakami Mountains, Japan
}

\author{
金 俊之 之 $^{\mathrm{a})}$ ，檜垣大助 ${ }^{\mathrm{b})}$ \\ Toshiyuki KON and Daisuke HIGAKI
}

\begin{abstract}
Many sediment movements, such as shallow landslides and sediment flows, occurred in the central part of the Kitakami Mountains in Iwate Prefecture, Japan, due to heavy rainfall during Typhoon Lionrock in August 2016. This paper aims to compare and examine the magnitude of sediment transports by this event and those in the early Holocene, focusing on the geomorphological background of this area. Geomorphological settings and scales of sediment production and transportation by the typhoon were studied through field surveys and detailed micro-geomorphological interpretation of the Red 3D Map produced from the LiDAR digital elevation model. The mountain slopes were classified as smooth crest slopes and upper valley head concave slopes of Last Glacial Period origin; lower valley head concave slopes, talus, and alluvial cones of Holocene origin; and other slopes. Although the annual probability of hourly rainfall intensity exceeded 300 years, sediment production appeared as shallow landsides with approximately $1 \mathrm{~m}$ in collapse depth either in the lower valley head concave slopes or around the lines of the convex slope break of Holocene origin. Shallow landslides also occurred on the other slopes and buried valley formed by continuous soil and rock creep on the valley slopes. These sediments were transported mainly by sediment flows and partially by debris flows during the typhoon. Moreover, the old debris flow deposits covered with $\mathrm{To}^{-} \mathrm{Cu}$ tephra $(5-5.5 \mathrm{Ka})$ in the upper tributaries of the Omoto and Hei Rivers were formed by sediment transportation in the early Holocene. These consist of boulders and gravels coarser in size than present river beds and sediment flow deposits by the typhoon. Some of these sediments moved from the lower valley head concave slopes. Gravel size analysis suggested that greater sediment production and transportation occurred in the early Holocene than during Typhoon Lionrock.
\end{abstract}

Key words : Kitakami Mountains, geomorphogical classification, old debris flow terrace, Red 3D Map, 2016 Typhoon Lionrock

本論は，岩手県北上山地中央部において,2016年 8 月台風第10号に伴う豪雨によって発生した表層崩壊について，その発生場を地 形的背景に着目して分析を行なった。現地調査と赤色立体地図を用いた詳細な地形判読により同台風で発生した土砂生産や移動を みると，年超過確率300年を超える時間雨量があったものの，土砂生産は「下位谷頭凹型斜面及びそれに連なる遷急線下方斜面」，「そ の他の斜面」,「埋積谷」に打ける崩壊深 $1 \mathrm{~m}$ 程度の表層崩壊であり, これら生産された土砂は土砂流として流出し，元の地形を大き く変化させるまでには至っていなかった。一方，流域内にはTo-Cu火山灰（約 $5,000 〜 5,500$ 年前降下）に覆われ，完新世前期の土 砂移動で形成されたとみられる大礫を含んだ「土石流段丘」が今回確認された。土石流段丘を構成する大砂等の一部は，To-Cu火 山灰降下前に「下位谷頭凹型斜面」を形成した土砂生産によるものとみられる。堆積土砂の磼径から土砂移動の規模を推定すると, 今回の台風による豪雨に比べて大規模な土砂移動が過去に存在したものと推察された。
\end{abstract}

キーワード：北上山地, 地形分類, 土石流段丘, 赤色立体地図, 平成28年台風第10号

\section{1.はじめに}

近年，局地的豪雨，ゲリラ豪雨に伴う土砂災害が全国

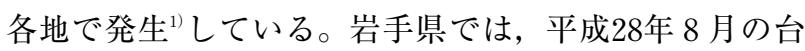
風第10号により東部を中心に累積雨量 $200 \mathrm{~mm}$ を越える 強雨域が形成され，岩泉雨量観測所（下閉伊郡岩泉町） では時間雨量 $62.5 \mathrm{~mm}$ (毎正時) の観測史上最大值を観 測する等，各地で豪雨となった ${ }^{2)}$ 。

岩手県内の河川では，岩泉町を流れる二級河川小本川 において洪水氾濫が発生し流域全体で死者 19 人，行方不 明者 2 人を出した ${ }^{3)}$ 。この豪雨によって岩手県内で 155 件 の土砂災害が発生している ${ }^{4)}$ 。大河原 ${ }^{5}$ は, 国土地理院に よる空中写真判読結果 ${ }^{6}$ や現地調査結果を元に岩泉町に おいて約1,400箇所の崩壊を含む土石流が発生し，土石 流により流出した土砂の多くが渓床堆積物起源であった

* 連絡著者/corresponding author

a) 岩手大学大学院連合農学研究科 (青森県庁)

United Graduate School of Agricultural Sciences, Iwate Univ. (Aomori Pref. Gov.)

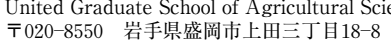

18-8 Ueda 3-chome, Morioka, Iwate

b) 弘前大学農学生命科学部

Faculty of Agriculture and Life Science, Hirosaki Univ.
と報告している。井良沢ほが ${ }^{7)}$ は，岩手県内での土砂災 害調査結果から大規模な崩壊による土砂流出は発生して おらず，前述の大河原 ${ }^{5}$ 同様，主に渓床堆積物や渓岸崩 壊により生産された土砂が土砂流形態で流出したものと 推定している。岡本ほか ${ }^{8}$ は，年超過確率300年を超えた 時間雨量が発生し，この降雨による斜面崩壊は山腹斜面 に比べて谷頭凹型斜面などの集水地形で多く発生してい ることを指摘した。

ところで，本台風で土砂災害が多発した岩泉町や宮古 市が位置する北上山地の斜面地形の発達過程を調査した 檜垣 ${ }^{9}$ は, 同山地は最終水期の寒冷な気候下において, 中・古生代の硬質な基盤岩が凍結破砕を受けて小磎と なって斜面を被覆し，これらの斜面堆積物は完新世の崩 壊や土石流物質になったとしている。

地形発達と現在の土砂移動現象の関係については大

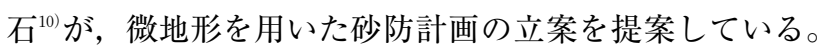
従来，砂防計画における広域調査は空中写真をベースに 実施されてきたが，近年，航空レーザ計測の普及により 
高精度の地形測量デー夕が全国的に整備され，砂防分野 においても主として調査・計画に利用されるようになっ た（たとえば，坂井ほか $\left.{ }^{111}\right)$ 。さらに赤色立体地図 ${ }^{12)}$ のよ うに専門家以外でも視覚的に地形を把握しやすい表現方 法を用いた情報も公表されている。

一方，土砂災害防止に関連し，地域防災計画の策定や 避難勧告などを発令する市町村では人員・知識など体制 が不十分な実態があることから，実効性ある土砂災害警 戒避難体制構築のために行政・住民双方は，地域特性と くに土砂災害実績の少ない地域では，過去の土砂移動を 示す地形情報の提供が必要である $\left(\right.$ 金ほか $\left.{ }^{13}\right)$ 。

この点で，北上山地は，土砂災害実績が少なく，また 最終水期の周水河作用と完新世の崩壊・土石流の影響を 受けて斜面地形が形成されたとされる特徽的な地域)で ある。そこで, 本研究では, 観測史上最大の降雨により 多数の土砂災害が発生した同地域における今後の土砂災 害警戒避難体制の構築に役立てるため，北上山地の地形 的背景から台風第10号豪雨による土砂生産・移動実態を 明らかにすることを目的とする。

\section{2. 調查地域の概要}

調査地域は，図- 1 に示す北上山地中央部に位置する 岩手県下閉伊郡岩泉町の二級河川小本川流域である。

\section{1 調査地域の選定}

調査地域は，概ね同じ地質分布域 估生代後期〜中生 代の粘板岩及び砂岩（チャート薄層を伴う）\}で台風第10 号豪雨による土砂移動が発生した範囲，かつ以下に示す (1)及び(2)の基礎データが存在する範囲を対象とした（図 -1 に破線で図示)。

(1) 台風第10号が通過した後，岩手県により航空レー ザ計測がなされた範囲

(2) 国土地理院の写真判読結果において土砂移動が確 認でき，かつ明瞭な崩壊地が認められる範囲

\section{2 地形}

北上山地の地形は，早池峰山（標高 $1914 \mathrm{~m} ）$ とその周 辺を除くと，標高 $1400 \mathrm{~m}$ 以下の起伏の小さな山地で構成 されている (たとえば，田村ほか $\left.{ }^{14)}\right)$ 。図 - 1 に調査地 域の $250 \mathrm{~m}$ 谷埋めの接峰面を示すが，調査地域において は，南側に標高 $1200 \mathrm{~m}$ 前後の峰が分布しており，北上山 地の全体的な傾向と同様に起伏にそしい地形が分布する。 調査地域中央部には二級河川小本川が西から東へ流下し, 南北から支川が入る。当該地域は，一般に土砂災害の発 生が少ない地域として知られ (川村ほか $\left.{ }^{15)}\right)$ ，また谷密 度 ${ }^{16)}$ からみても開析が進んでいない地域 ${ }^{17)}$ であり, 尾根 · 谷の比高が小さく斜面崩壊が生じにくい地域の特徴を有 している。

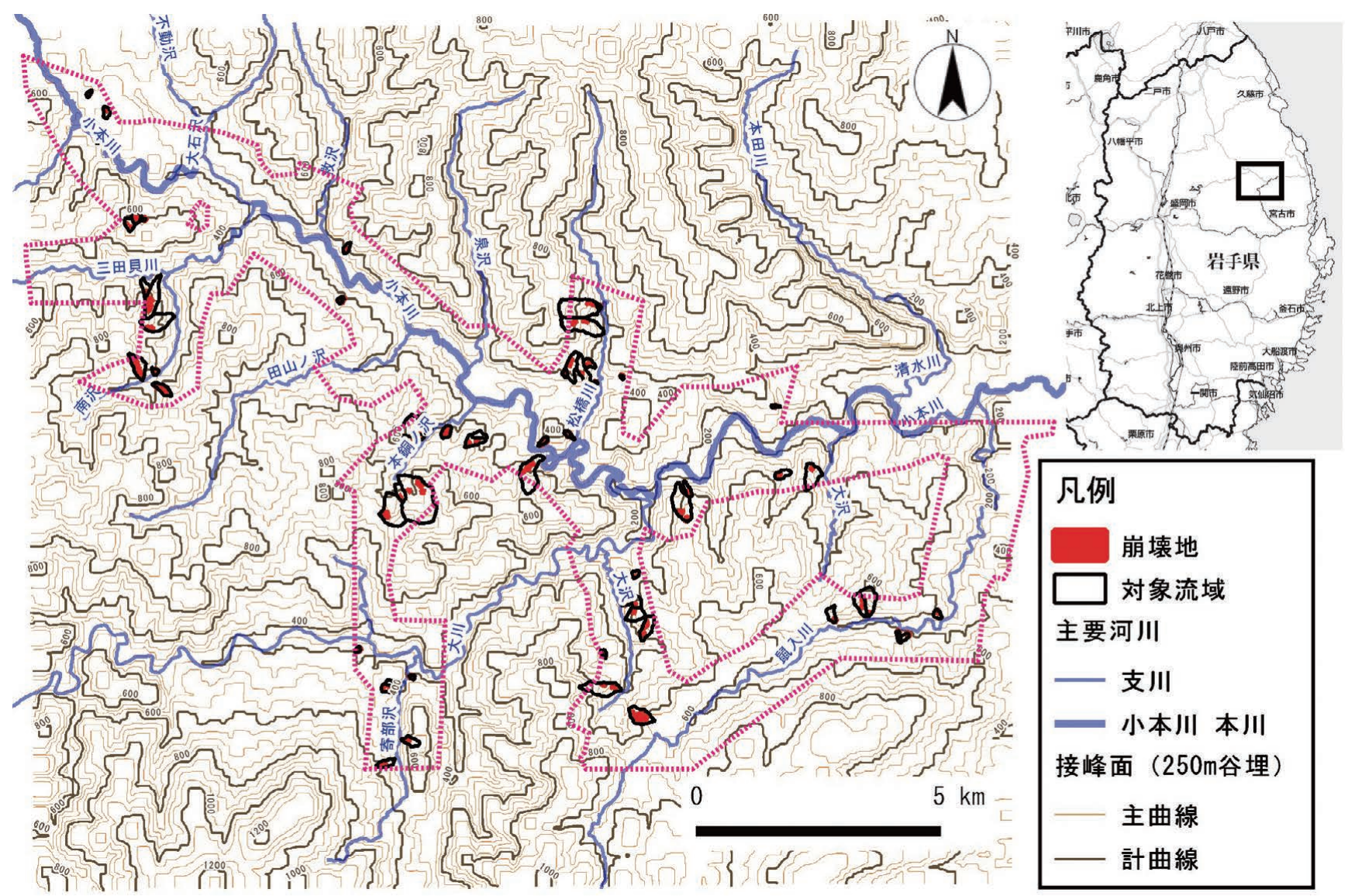

図- 1 調查位置図

Fig. 1 Study area 


\section{3 地質}

調査地域を含む北上山地北部の地質は，古生代後期〜 中生代の粘板岩及び砂岩（チャート薄層を伴う），これ らに貫入する中生代の花崗岩を主とする（吉田ほか $\left.{ }^{18}\right)$ 。 調査地域を概観すると，概ね上述の粘板岩及び砂岩が主 体であり，まとまった石灰岩の岩体や花崗岩は分布して いない。

\section{4 北上山地の斜面地形発達}

檜垣 ${ }^{9}$ は，北上山地における最終水期以降の斜面地形 発達を明らかにするにあたり図 - 2 に示す 8 つに斜面地 形を区分し，各斜面の地形及び斜面物質の特徵，また示 標テフラと地形形成期の関係を検討している。

各斜面地形や斜面堆積物と示標テフラとの関係から， 北上山地では，寒冷環境下における凍結融解による斜面 物質の移動期が少なくとも 3 回存在した。それらは最終 間氷期以前の水期, 5 万年前前後の時期, $3 \sim 4$ 万年前から 1 万数千年前頃の最終水期後半と推定され，その前後の 時期は，斜面物質の移動が相対的に不活発であったと推 察している。

これらのうち完新世,すなわち現在の環境 (土砂生産・ 移動）で形成された山地斜面地形としては，最終水期後 半のソリフラクションを主とする斜面物質移動が終了し た後に発生した崩壊によって形成された下位谷頭凹型斜 面が挙げられる（図-2の 6 ）。また小渓流の谷出口に は沖積錐が形成されていることを踏まえ，水期の凍結融 解により生産され斜面に残存している岩屑が，完新世に おける崩壊予備物質としての役割を果たしているとした。

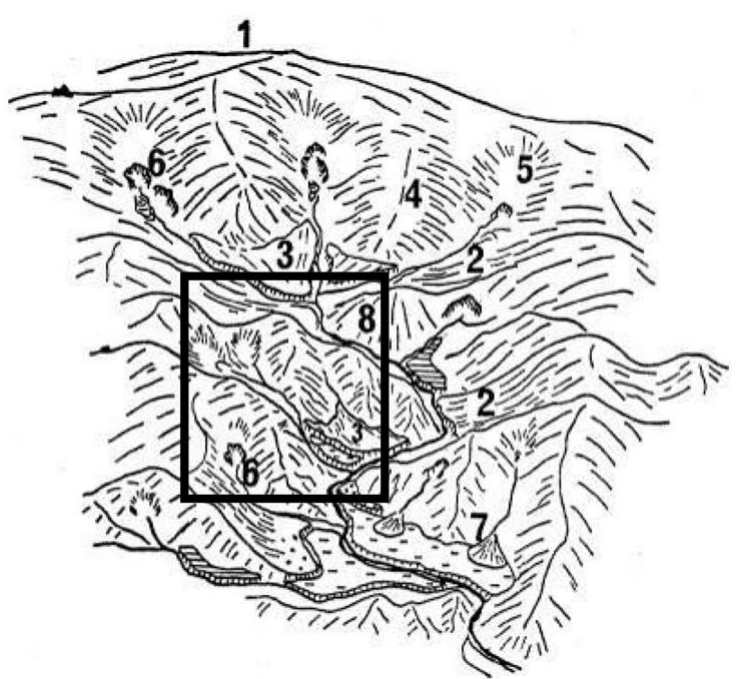

1 : 山頂緩斜面, 2 : 山麓緩斜面, 3 : 扇状地状緩斜面, $4 ：$ 平滑尾根型斜面， 5 ：上位谷頭凹型斜面， $6 ：$ 下位谷頭凹 型斜面， 7 ：崖錐・沖積錐，8：その他の山腹斜面

\section{図一 2 北上山地の斜面地形概念図 ${ }^{9}$}

Fig. 2 Schematic sketch of the slope morphology of Kitakami Mountains

（図中の $\square$ は後述する図ー 7 に対応）

\section{3. 平成28年台風第10号の概要}

\section{1 降雨概要}

盛岡地方気象台 ${ }^{2}$ によれば，調查地域周辺において 8 月29日 0 時から 8 月31日 12 時まで降雨が観測されている。 調査地域近傍の岩泉雨量観測所では248mmを観測し， 周辺地域に比べて多量の降雨があった。また同観測所に おける日最大 1 時間降水量 $70.5 \mathrm{~mm}$ （8 月 30 日 $17 ： 21$ か ら18：21まで）は, 1976年に統計を開始して以来，観測 史上 1 位の記録を更新している。

岡本ほか ${ }^{8)}$ は，本台風に伴う降雨について確率年を分 析して岩泉雨量観測所の最大時間雨量は305年，日雨量 は21.7年と算出し, 300年に 1 度程度しか起こりえない極 めて激しい時間降雨があったとしている。

\section{2 台風第10号豪雨による土砂生産・移動}

台風第10号豪雨による北上山地での土砂生産・移動状 況を既往報告から以下にまとめる。

大河原 ${ }^{5}$ ，井良沢ほか ${ }^{77}$ は，現地調査から大規模な崩壊 による土砂流出は発生しておらず，河床堆積物の再移動 や渓岸崩壊による土砂流出が主体であることを確認した。 岡本ほか ${ }^{8)}$ は，地質条件から同地域は保水力が少ない地 域であり，また現地で山腹斜面の表土層が薄いことを確 認した結果から，降雨は速やかに渓流域に流出して渓岸 崩壊や渓床堆積物の侵食により大量の土砂が流出したと 推定している。一方で滝澤ほか ${ }^{19)}$ は, 流出形態は土砂流 が総じて多いが，土石流形態による土砂移動も一部の渓 流で確認している。渡辺ほか ${ }^{20)}$ は，氾濫域の被災家屋等 の大半は, 原形を留めていることを指摘し, これは井良沢 ほか7 が指摘した土砂流が主体であったことと符合する。

\section{4. 台風第10号豪雨による崩壊と地形分類との関係性}

\section{1 研究方法}

図－3に研究フローを示す。土砂生産・移動範囲の確 認は, $2.1 に$ 前述した範囲で行った。土砂生産・移動が認 められた範囲において，岩手県が台風第10号後に計測し た航空レーザ計測データ（地図情報レベル500, 1mメッ シュDEM ${ }^{211}$ から作成した赤色立体地図を元に崩壊地を 抽出し, さらに当該崩壊地が発生した流域の区分及び地

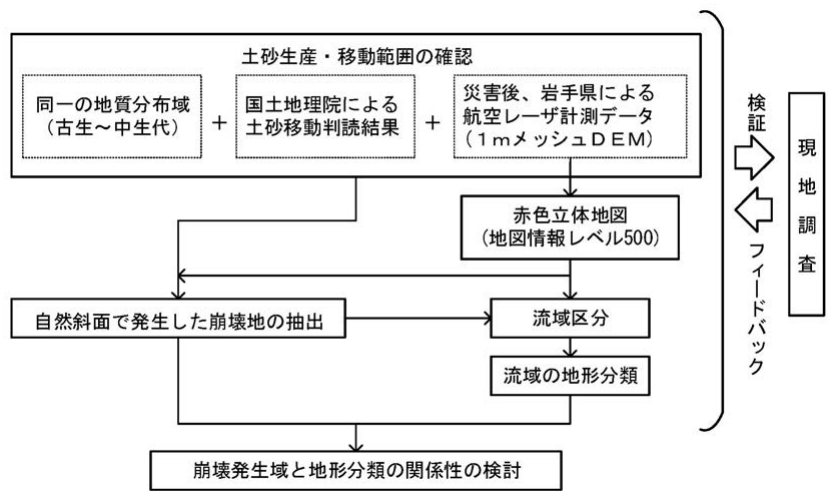

図一 3 研究方法

Fig. 3 Study method 
形分類を行い，分類された地形と崩壊発生域の位置関係 を検討した。

本論において「土砂生産」は豪雨等の誘因により斜面 または谷底部から土砂が新たに発生する現象（主に斜面 での崩壊)，「土砂移動」は生産された土砂が下流側へ移 動する現象（堆積土砂の二次侵食は土砂生産に含み，移 動には含めない）とする。

\section{2 対象とする崩壊地及びその範囲}

\section{(1) 対象崩壊地}

崩壊地と地形分類の関係性を検討するため, 対象は, 人為影響の可能性がある崩壊を除外し，自然斜面におい て発生した崩壊地とした。なお調查地域における主な人 為影響としては，林道沿いの人工斜面や排水不良に起因 した崩壊が挙げられる。

\section{( 2 ) 対象崩壊地の抽出範囲}

崩壊地は，発生域だけではなく，周囲の斜面との高低 差すなわち傾斜変換線（遷急線）が形成された崩壊は流 送域を含めて抽出した。台風第10号豪雨による崩壊は後 述するように崩壊深が約 $1 \mathrm{~m}$ であるが，現地調查におい て周囲の非崩壊斜面と遷急線により概权分けられること を確認した。この遷急線の有無を目安とし，赤色立体地 図において傾斜変換線が確認できる範囲は，今回崩壊し たものと判断した。

図－4には，国土地理院撮影の空中写真，赤色立体地 図，崩壊地の横断図を用いた具体的な崩壊地の抽出事例 を示す。空中写真及び赤色立体地図には抽出した崩壊地 の範囲を点線で示した。同図(1)は崩壊面の下方が直接河 道に接し，一連の斜面が崩れた崩壊地，(2)は谷頭部の斜 面が崩れて崩積土が流下した崩壊地である。いずれの崩 壊地も空中写真では, 崩壊地縁辺部がやや樹木に覆われ ているが，赤色立体地図では傾斜変換線が形成されてい る。これを(1) A - A' 及び(2) B - B' 横断図でみると非崩壊 斜面と崩壊面の境界部には矢印で示した傾斜変換線が形 成されている。横断図には周囲から想定される崩壊前の 地表面を破線で示したが，この図からも平均的な崩壊深 が $1 \mathrm{~m}$ 程度とみられる。

崩壊範囲として，(1)は斜面上部の崩壊頭部から河道ま での範囲を抽出した。(2)は,下方斜面へ移行するにつれて 崩壊幅が狭くなり斜面から河道に遷移するので，赤色立 体地図に丸で示した地点までを崩壊範囲として抽出した。

以上，本論で定義づけた対象崩壊地の抽出結果を表一 1 に示す (図- 1 には，分布状況を図示)。崩壊地の全 数は118個，全崩壊面積は $43,800 \mathrm{~m}^{2}$ となった。ただし， 図－5に示す崩壊地の面積ごとの頻度分布をみてわかる ように, 崩壊面積が $10,000 \mathrm{~m}^{2}$ 超える崩壊地（面積約 $\left.14,500 \mathrm{~m}^{2}\right) 1$ 箇所が全面積の約 $1 / 4$ を占めることから， これを異常值として取り扱った場合，平均面積は $250 \mathrm{~m}^{2}$ /個，標準偏差 $390 \mathrm{~m}^{2}$ となる（表- 1 下欄）。なお異常值 と判断した崩壊は, 空中写真において複数の崩壊が密に 発生している範囲であり，赤色立体地図で確認すると空
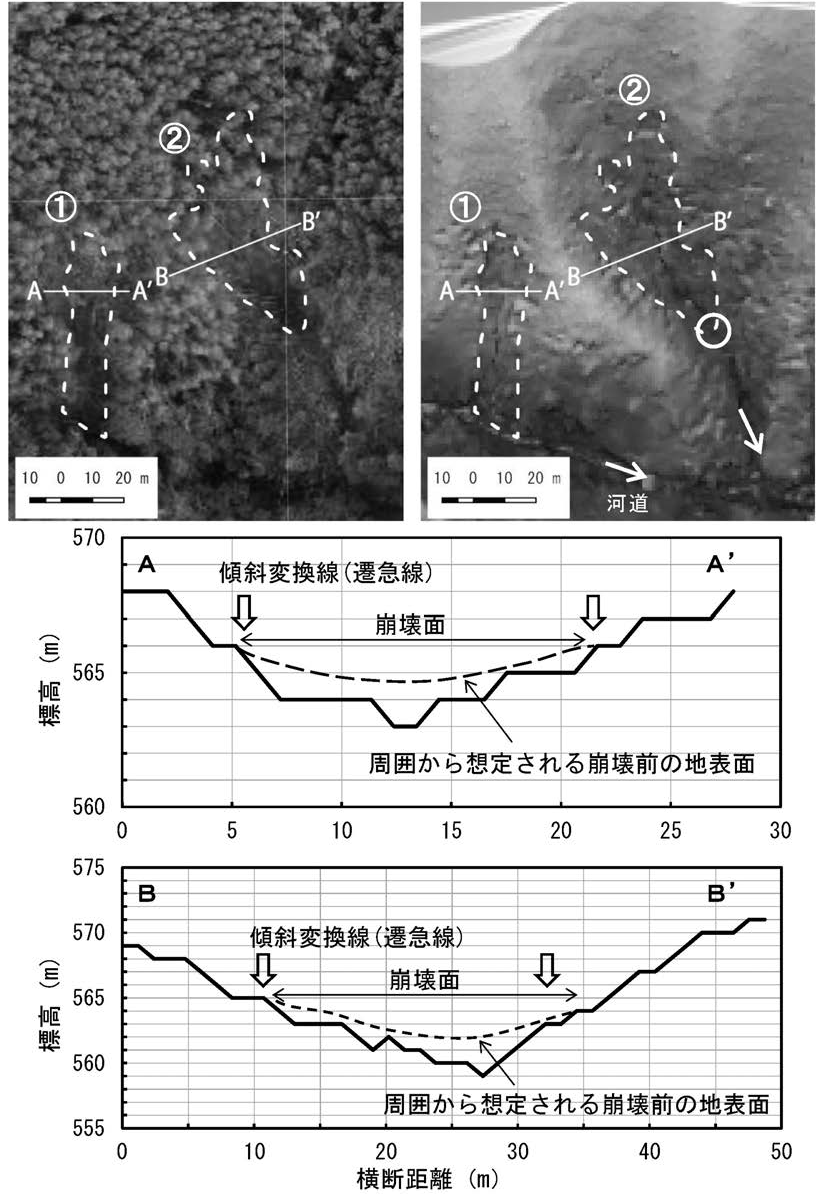

図一 4 崩壊地の抽出事例

Fig. 4 Examples of landslide recognition

中写真で非崩壊範囲とみられた崩壊地間の地表面も一連 で乱れていることから，崩壊地の区分が困難と考え，一 括として取り扱ったものである。

図- 5 から崩壊面積 $500 \mathrm{~m}^{2}$ 以下が全体の約 9 割を占め

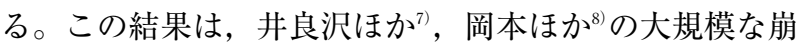

\section{表- 1 崩壊地の抽出結果}

Table 1 Results of the extracted landslide

\begin{tabular}{|r|r|r|r|}
\hline 崩壊箇所数 & 全崩壊面積 $\left(\mathrm{m}^{2}\right)$ & 平均面積 $\left(\mathrm{m}^{2} /\right.$ 個 $)$ & \multicolumn{1}{|c|}{ 標準偏差 $\left(\mathrm{m}^{2}\right)$} \\
\hline \hline (全数) 118 & 43,800 & 370 & 1,360 \\
\hline $117 \%$ & 29,400 & 250 & 390 \\
\hline
\end{tabular}

※異常値（1箇所の崩壊地）を除いた場合の崩壊地面積等

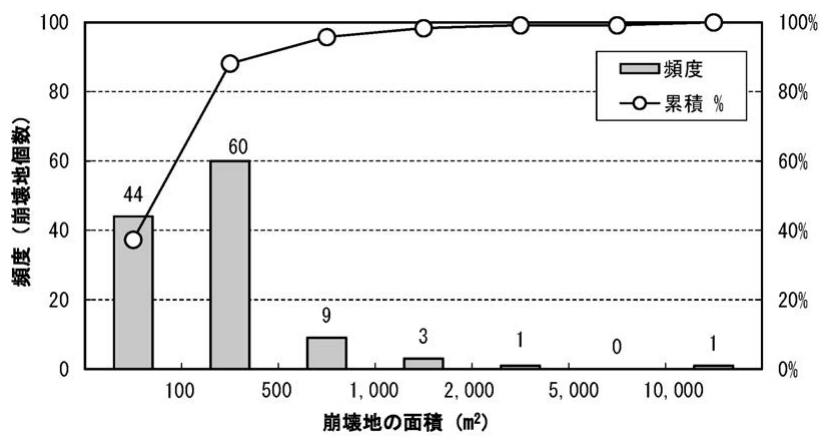

図一 5 崩壊地面積の頻度分布

Fig. 5 Frequency distribution for each area rank 
壊が少なかったとの報告と調和的である。

崩壊地の平均的な幅と長さをGISにより個別に計測し プロットしたものを図ー6 示す（異常值を除く）。長さ は斜面方向の長さ, 幅はそれに直行する方向で平均的な 箇所を計測している。図－6に破線の楕円で示す幅 $10 \mathrm{~m}$ 以下，長さ $50 \mathrm{~m}$ 以下に集中しており，縦長の比較的小規 模な崩壊地が多数を占める。

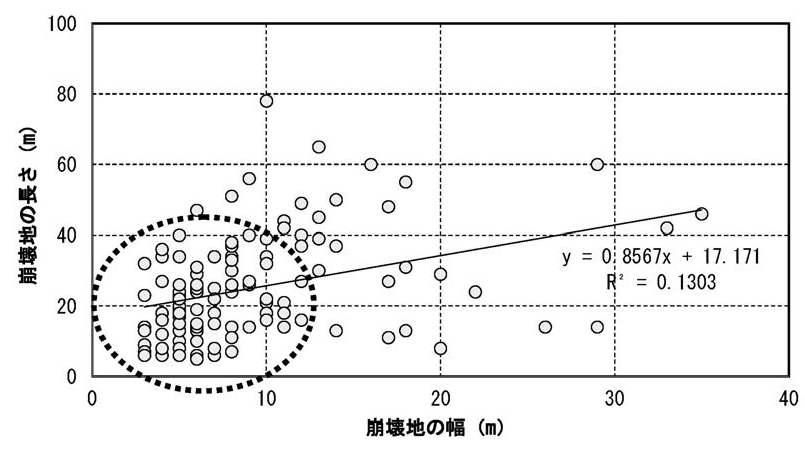

図一 6 崩壊地の幅と長さの関係

Fig. 6 Relationship between the width and length of landslides

\section{（３）崩壊が生じた流域}

自然斜面で崩壊が発生した流域数を表 -2 上欄に示す (図- 1 に分布状況を図示)。調査地域において合計63流 域が抽出された。また，表－ 2 下欄には林道沿いで崩壊 が発生している流域，すなわち今回の崩壊が人為的な影 響で発生している可能性がある流域数を併記した。対象 地域内でみれば，自然斜面で崩壊が発生した流域数と同 程度存在している。

\section{3 流域の地形分類}

小本川沿いでは岩手県 ${ }^{21)} に よ り$ 災害直後，航空レーザ 計測が実施され，赤色立体地図が作成されている。赤色 立体地図による地形判読（たとえば (国研) 土木研究所 ${ }^{22}$, 高山ほか ${ }^{23)}$ ) の事例もあることから，本論においても同 図を用いた地形判読により流域の地形分類図を作成する こととした。

ここで図 - 2 のうち，台風第10号豪雨により土砂移動 が生じた範囲における主たる地形要素に対応した地形概 念図を図 - 7 に示す。

本論では北上山地の地形的背景と台風第10号豪雨によ る土砂移動の関係を検討することから，檜垣 ${ }^{9}$ が分類し た地形要素（図一 2 に前述）のうち，完新世に形成され た「下位谷頭凹型斜面」に注目した。下位谷頭凹型斜面 は，谷頭部に形成された凹型の斜面と流域の下流側でそ

\section{表－2 流域区分結果}

Table 2 Results of the catchment classification

\begin{tabular}{r|r|r|r|}
\hline \multicolumn{1}{|c|}{ 流域数 } & 合計流域面積 $\left(\mathrm{km}^{2}\right)$ & 平均值 $\left(\mathrm{km}^{2} /\right.$ 渓流 $)$ & 標準偏差 $\left(\mathrm{km}^{2}\right)$ \\
\hline 63 & 4.43 & 0.07 & 0.09 \\
\hline 67 & 4.17 & 0.06 & 0.07 \\
\hline 上欄 : 自然斜面で崩壊が発生した流域 \\
\hline
\end{tabular}

下欄：人為的な影響で崩壊が発生した可能性がある流域

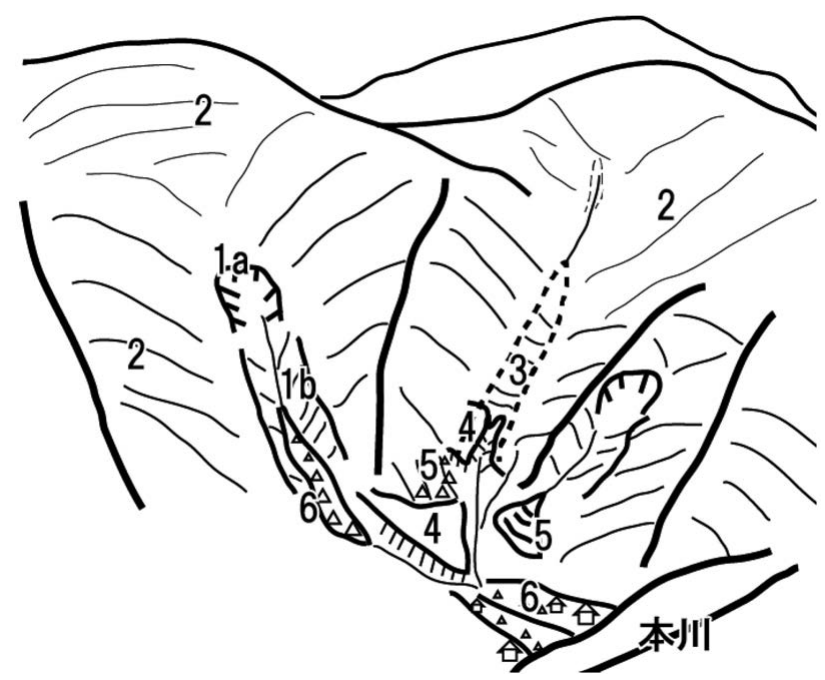

1：下位谷頭凹型斜面及びそれに連なる遷急線下方斜面（1 $\mathrm{a}$ ：下位谷頭凹型斜面， $1 \mathrm{~b}$ ：連なる遷急線下方斜面), 2 : そ の他の斜面，3：埋積谷，4：段丘，5：崖錐・沖積錐，6：渓 床堆積土砂

\section{図ー 7 台風第10号豪雨により土砂移動が生じた範囲の地形 概念図}

Fig. 7 Schematic sketch of the topography where sediment transport was triggered by Typhoon Lionrock

れに連続する斜面が形成されていることから，この凹型 斜面に連なる一連の斜面を「下位谷頭凹型斜面及びそれ に連なる下方斜面」として判読した。下位谷頭凹型斜面 に連なる下方斜面は，田村 ${ }^{24)} の$ 分類による「下部谷壁斜 面」や「下部谷壁凹型斜面」に相当するが，北上山地に おいては「下位谷頭凹型斜面」と同じ完新世に形成され た一連の地形要素として取り扱うことが適当と考え，一 つの地形要素として設定した。

「その他の斜面」は，檜垣 ${ }^{5}$ における山頂緩斜面や上位 谷頭凹型斜面などの水期起源の斜面も含めて一括りとし たものである。「埋積谷」とは過去に谷が埋積されてな だらかになっている範囲を指す。

判読した地形要素の特徵及び判読時の目安を表ー 3 に 示す。地形分類の考え方については，大石 ${ }^{25}$ 及び鈴木 ${ }^{17}$ を参考に設定した。同表には左から赤色立体地図，中央 に判読例，右には国土地理院の電子地形図25000を図示 した。本論では，ある程度の面的広がりを有する流域を 対象として検討を進める目的から縮尺 $1 / 2,500$ の赤色立 体地図により判読を行うこととした。なお地形分類結果 については現地調査により検証した上で検討を進めた。

\section{4 崩壊発生域と地形分類の関係}

4. 3で述べた方法で分類した地形要素とその構成面積 を表 -4 に示す。同表では地形要素ごとの崩壊面積も併 記した。表－4 から「2：その他の斜面」の面積が対象 流域全体の約 8 割を占め，次いで約 1 割が「1：下位谷 頭凹型斜面及びそれに連なる遷急線下方斜面」となって おり，この 2 種類の地形要素が大半の面積を占める。ま た崩壊はこれらの地形要素において, 全体の約 9 割が発 
表一 3 地形要素とその特徵

Table 3 Geomorphological unit and their characteristics

\begin{tabular}{|c|c|c|c|c|c|}
\hline \multirow{2}{*}{ ID } & \multirow{2}{*}{ 地形要素* } & \multirow{2}{*}{ 説明·判読目安 } & \multirow{2}{*}{\multicolumn{3}{|c|}{ 判読例 }} \\
\hline & & & & & \\
\hline 1 & $\begin{array}{l}\text { 下位谷頭凹 } \\
\text { 型斜面及び } \\
\text { それに連な } \\
\text { る遷急線下 } \\
\text { 方斜面 } \\
\text { (下斜) }\end{array}$ & 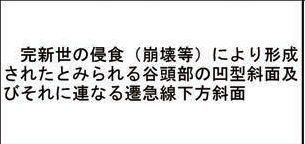 & & & \\
\hline 2 & $\begin{array}{l}\text { そのの他の斜 } \\
\text { (他斜) }\end{array}$ & 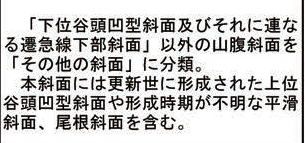 & & & \\
\hline 3 & $\begin{array}{l}\text { 埋積谷 } \\
\text { (埋谷) }\end{array}$ & 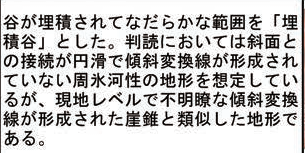 & & & \\
\hline 4 & $\begin{array}{l}\text { 段丘 } \\
\text { (段丘) }\end{array}$ & $\begin{array}{l}\text { 渓床堆積土砂などの堆積地形で段兵化 } \\
\text { むた地形を段丘」とした（段丘崖含 } \\
\text { む)。 }\end{array}$ & & & \\
\hline 5 & $\begin{array}{l}\text { 㟶錐・沖積 } \\
\text { 崖沖) }\end{array}$ & 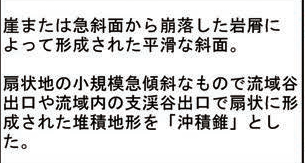 & & & \\
\hline 6 & $\begin{array}{l}\text { 滛床堆積土 } \\
\text { (溪土) }\end{array}$ & 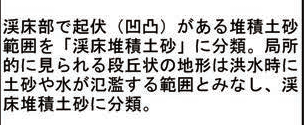 & & & $\lim _{1}$ \\
\hline 7 & $\begin{array}{l}\text { 人工改変地 } \\
\text { (人工) }\end{array}$ & 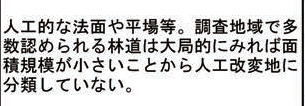 & & & 移协保洛崖 \\
\hline
\end{tabular}

表一 4 地形要素及び崩壊地の面積

Table 4 Area and area ratio for each geomorphological unit and landslides

\begin{tabular}{|c|c|c|c|c|c|}
\hline \multirow{2}{*}{\multicolumn{2}{|c|}{ 地形要素 }} & \multicolumn{2}{|c|}{ 分布面積 $\left(1,000 \mathrm{~m}^{2}\right)$} & \multicolumn{2}{|c|}{ 面積率（\%） } \\
\hline & & (1)地形要素 & (2) 崩壊地 & 地形要素 & 崩壊地 \\
\hline 1 & 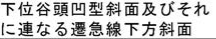 & 550.5 & 17. 6 & 12. $4 \%$ & $39.0 \%$ \\
\hline 2 & その他の斜面 & $3,689.8$ & 25.7 & $83.2 \%$ & $57.0 \%$ \\
\hline 3 & 埋積谷 & 57.0 & 1.4 & 1. $3 \%$ & $3.0 \%$ \\
\hline 4 & 段丘 & 12.6 & 0.0 & $0.3 \%$ & $0.0 \%$ \\
\hline 5 & 崖錐・沖積錐 & 53.4 & 0.3 & $1.2 \%$ & $0.7 \%$ \\
\hline 6 & 渓床堆積土砂 & 72.5 & 0.1 & $1.6 \%$ & $0.2 \%$ \\
\hline 7 & 人工改変地 & 0.6 & 0.1 & $0.0 \%$ & $0.2 \%$ \\
\hline & 合計 & $4,436.4$ & 45.2 & & \\
\hline
\end{tabular}

\section{生している。}

次に崩壊地の抽出及び地形分類結果を元に図 - 8 には 地形要素ごとの面積率，崩壊地の分布面積率，地形要素 に占める崩壊地の占有率（表－4の(2) $\div$ (1)の百分率）を 示した (人工改変地の表記は省略)。崩壊地が複数の地 形にまたがる時は，それぞれの面積を算出している。

崩壊地の占有率は，表 -4 地形要素の面積率から逆転 し，「1：下位谷頭凹型斜面及びそれに連なる遷急線下 方斜面」において最も高く, 次いで「 3 : 埋積谷」, $「 2$ ： その他の斜面」の順に高い。

これは, 占有率の点で台風第10号豪雨による崩壊が流 域上部に分布する「2：その他の斜面」に比べて完新世 に形成された「1：下位谷頭凹型斜面及びそれに連なる

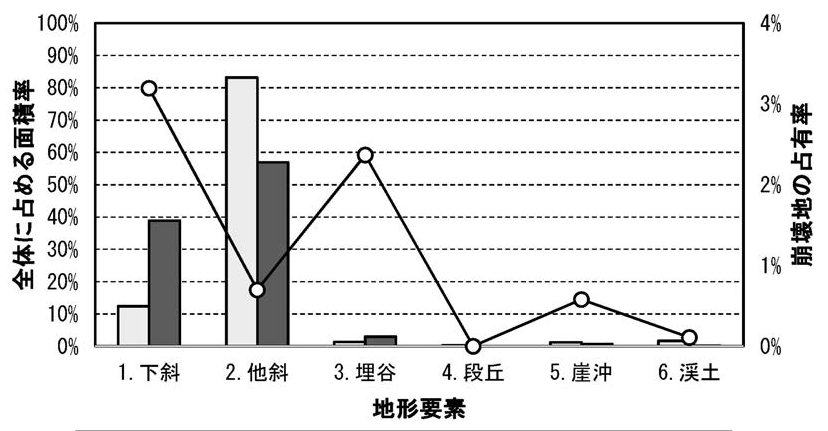

戸地形要素面積率 戸崩壊地面積率 一○一占有率

図ー8 崩壊の発生した地形要素

Fig. 8 Area and susceptibility of landslides by Typhoon Lionrock for each geomorphological unit

遷急線下方斜面」において多数生じていることを意味す る。羽多野 ${ }^{26) 27(28)}$ は，崩壊の発生位置と遷急線との関係 を「後氷期開析前線」として提唱したが，調査地域にお いてもこれと同様に完新世に形成されたとみられる地形 要素で崩壊が相対的に多く発生している。

地形要素, 抽出した崩壊地118個について, 発生域の 地形分類との関係，現在の侵食状況，周囲の地形面との 差異を赤色立体地図により詳細に確認したデータベース を作成し，この情報を元に現地調査をおこなった結果を 以降にまとめる。

( 1 )「下位谷頭凹型斜面及びそれに連なる遷急線下方斜 面」における崩壊地の状況

赤色立体地図で詳細にみると地表面を削り込むような 発生形態の崩壊は少なく，元来凹型斜面であり，ガリー 状に侵食されていた斜面の谷頭部が崩壊する形態がよく 見られた。これらの崩壊地を調査したところ写真 - 1 (a) に示すように，表土層の厚さが $1 \mathrm{~m}$ 未満の斜面が崩壊 • 流出している状況が確認された。渓岸沿いの崩壊地は渓 床土砂の移動に起因し侵食を受けて発生した状況も認め られた。総じて崩壊面や渓岸沿いには，写真－1（a)破 線で示すように基岩（粘板岩）が確認でき，崩積土が斜 面内で残存した場所は少ない。

\section{( 2 )「その他の斜面」における崩壊地の状況}

赤色立体地図で詳細に確認すると大小様々な崩壊形態 であるが，共通して言えることは崩壊深が基岩の深部に 及ぶ崩壊は発生しておらず，斜面での多量の土砂生産が 発生して，それらが大規模に流出する現象は今回の豪雨 で生じていない。この点では，「下位谷頭凹型斜面及び それに連なる遷急線下方斜面」での崩壊と同様である。

$\lceil 2$ ：その他の斜面」で発生した崩壊地の一部におい て，崩壊面に褐色風化火山灰層が認められた 泻真 -1

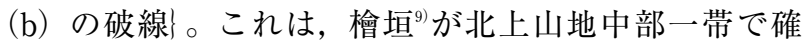
認した分蝎色風化火山灰 (大上ほか ${ }^{29}$ ) と推定される。 このテフラの下に礫が認められることも踏まえると， $\left\lceil 2\right.$ : その他の斜面」の構成物質には檜垣 ${ }^{9}$ が指摘した水 期の凍結融解により生産された斜面堆積物も含まれる可 能性がある。 
写真 -1 の崩壊地において，今回の崩壊による流出土 砂，崩壊地脚部に残存する土砂，分褐色風化火山灰層に 覆われる土砂，それぞれの礫径を計測した（図－9）。 磁径は，平均的な礫径の堆積物範囲に $1 \mathrm{~m}$ 四方のコド ラートを設け，そのコドラート内の礫を最大礫径から順 に20個，短辺と長辺を計測し，その平均を平均砂径とし た。図 - 9 に平均礫径と頻度，累加曲線を示す（個数基 準)。分褐色風化火山灰層下の斜面堆積物は, 粘土混じ りの角礫により構成され礫径は $10 \mathrm{~cm}$ 以下が主体である。 一方, 今回の崩壊土砂及び土石流堆は, これに比べて大 きく角礫〜亜角礫から構成され, 角礫主体の土石流堆で は最大 $100 \mathrm{~cm}$ の礫も確認された。このことから分褐色風 化火山灰層下の斜面堆積物と今回の崩壊土砂及び土石流 堆は，土砂生産及び運搬プロセスが異なるものと推定さ れる。

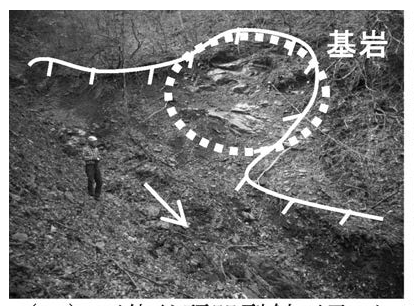

（a）下位谷頭凹型斜面及ひ それに連なる遷急線下方斜面

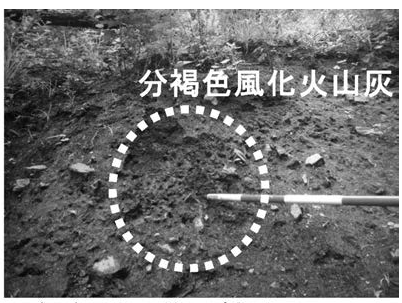

（b）その他の斜面

写真- 1 崩壊地の事例

Photo 1 A case of landslide

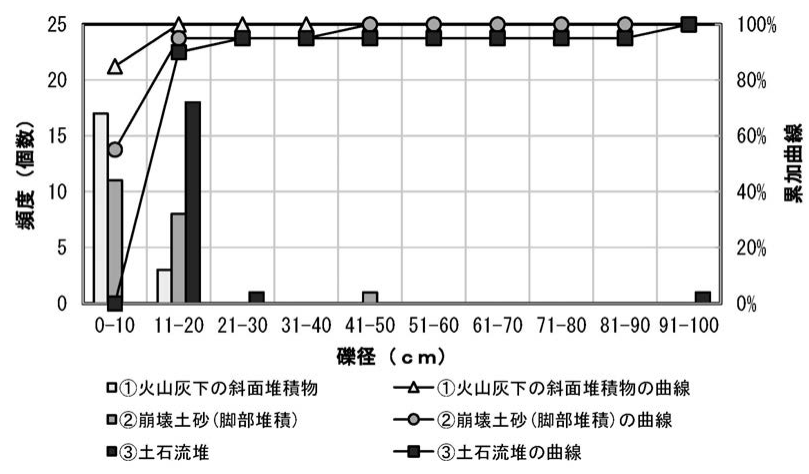

図-9 礫径の粒度分布

Fig. 9 Gravel size distribution

\section{( 3 )「埋積谷」における崩壊地の状況}

周囲の斜面から傾斜変換線を持たずに連続する埋積谷 は, 調查地域における小渓流谷底部において比較的よく 認められ，傾斜は $25^{\circ} \sim 35^{\circ}$ の勾配を呈する。今回の災害 では，埋積谷の下流端部で崩壊した事例が多く認められ る。これらの崩壊地を調査したところ, 湧水地点となる 埋積谷下流端部で崩壊している状況が認められた。

埋積谷を構成する堆積物は礫径 $20 \mathrm{~cm}$ 前後の角礫が主 体であることから，周辺斜面からの岩屑が谷を埋めたも のと推定される。

\section{5 台風第10号豪雨による土砂生産が地形発達に果 たした役割}

台風第10号豪雨により発生した崩壊は，完新世に形成
された「下位谷頭凹型斜面及びそれに連なる遷急線下方 斜面」，完新世以前の地形面を含む「その他の斜面」，岩 屑等により谷底部が埋積された「埋積谷」において発生 していた。これらの崩壊地の細部を現地調査及び赤色立 体地図により確認したところ，崩壊深 $1 \mathrm{~m}$ 未満の表層崩 壊が大半を占めていた。このことから年超過確率300年 を超える降雨があったものの，流域内の地形を大きく変 化させるような土砂生産現象にはいたらなかったと言え る。一方, 水期に凍結融解で生産された斜面堆積物が「そ の他の斜面」の一部で確認されたことから，これら小礫 からなる斜面堆積物の一部も今回の崩壊で流出した可能 性がある。

\section{5. 完新世の土砂生産・移動}

\section{1 完新世の土砂移動痕跡}

小本川や調查地域南側に位置する閉伊川の本川沿いに は何段かの河岸段丘が存在し，それぞれ形成年代が把握 されている ${ }^{30)}$ さこのうち「S-1段丘」は，現河床から 約 $5 \sim 10 \mathrm{~m}$ 前後の高さで本川・支川によく分布し，非常 に連続性が良い段丘である。 $\mathrm{S}-1$ 段丘は，To-Cu火山 灰 ${ }^{31}$ (十和田中掫軽石：約 5,500 年前降下）に相当する安 家火山灰 (町田ほか ${ }^{32)}$ ，菊池ほか ${ }^{33)}$ ) を載せ，約 10,000 $\sim 12,000$ 年前降下の分褐色風化火山灰 (岩泉町 ${ }^{34}$, 町 田 $\left.^{35}\right)$ が載らないことから完新世に形成されたと推定さ れている。

赤色立体地図を用いて小本川及び閉伊川の支川に分布 する河岸段丘面を判読したところ，本川に分布するS 1 段丘に連続する高さの段丘がいくつかの流域で認めら れた。これらの段丘は，背後斜面からの崖錐に覆われる こともあるが，表－ 5 に示す 3 地点では，段丘面を構成 する土石流堆積物が認められた。これらの土石流堆積物 は，黄灰色～紫灰色のガラス質の火山灰（層相や層位， 厚さの点でTo-Cu火山灰に相当）に覆われていた。

調査地点の概要を表 - 5 に示す。これらの段丘化した 土石流堆積物がみられた地点上流の流域面積は，全て約 $2 \mathrm{~km}^{2}$ 前後である。段丘面の勾配と現河床の渓床勾配に 大きな差はなく，現河床の渓床勾配 ${ }^{36)}$ からみると，調査 地点 1,2 は土石流の堆積区間，調查地点 3 は流下・堆積 区間に相当すると考えられる。いずれの調查地点でも台 風第10号豪雨による土砂流出が認められた（井良沢ほ か $^{7)}$ ことから各地点で段丘を構成する堆積物，今回の

\section{表一 5 調査地点概要}

Table 5 Overview of the study sites

\begin{tabular}{|c|c|l|r|c|}
\hline $\begin{array}{c}\text { 調査 } \\
\text { 地点 }\end{array}$ & 本川名 & $\begin{array}{c}\text { ()内の値は調査地点のJGD2000 } \\
\text { 平面直角座標系第10系座標値 }\end{array}$ & $\begin{array}{c}\text { 流域面積 } \\
\left(\mathrm{km}^{2}\right)\end{array}$ & 渓床勾配 \\
\hline \hline 1 & 小本川 & $\begin{array}{l}\text { 左支川救沢 } \\
(70837.933,-11978.786)\end{array}$ & 1.60 & $1 / 9\left(6^{\circ}\right)$ \\
\hline 2 & 小本川 & $\begin{array}{l}\text { 右支川大川 } \\
(76611.618,-21785.711)\end{array}$ & 2.06 & $1 / 13\left(4^{\circ}\right)$ \\
\hline 3 & 閉伊川 & $\begin{array}{l}\text { 左支川巣喰沢 } \\
(69889.682,-42568.601)\end{array}$ & 2.10 & $1 / 5\left(11^{\circ}\right)$ \\
\hline
\end{tabular}

※流域面積は調査地点上流の面積を計測した。 
土砂移動及びそれ以前に堆積していた河床堆積物の礫径 を調査・分析した。礫径は, 4.4で用いた方法と同じ手法 により調查し，個数基準で評価及び表記した。

\section{2 調查地点の状況}

調査地点 1 から 3 の平面図を図-10に示す。破線で示 す範囲が $\mathrm{S}-1$ 段丘に相当する段丘面である。各地点に おける現河床から段丘面までの比高は，調查地点 1 及び 2 で約 $5 \mathrm{~m}$, 調査地点 3 で約 $7 \mathrm{~m}$ である。調査地点 3 で 確認できる段丘面は背後斜面からの岩屑に覆われており， 一部では崖錐が形成されていた。

図-11には段丘面を覆う To-Cu火山灰及びその下位に 堆積する㗂層の柱状図を示す。いずれも段丘面上の黒色 土下位に層厚の差異はあるものの $\mathrm{To}-\mathrm{Cu}$ 火山灰が礫混じ り粘土マトリクスの亜角砂層を覆っている状況が認めら れた。

図ー12には各調查地点における(1)今回の土砂移動によ る堆積物, (2)それ以前に堆積していた河床堆積物, (3)To
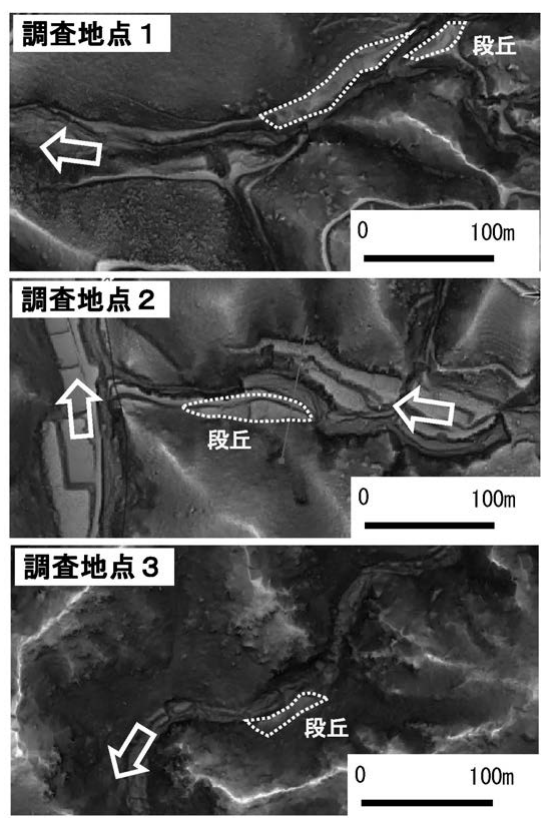

図ー10 完新世に形成された土石流段丘 （破線内の範囲：土石流段丘）

Fig. 10 Study site of debris flow terraces formed in Holocene (broken line : debris flow terrace)

$-\mathrm{Cu}$ 火山灰に覆われる段 丘堆積物の砂径調查結果 を示す。な㧍調査地点 3 では台風第10号豪雨によ る流出土砂が複数（A： 流域内の土石流堆, $\mathrm{B}$ : 土石流堆の上流での後続 流堆積物, $\mathrm{C}$ : 谷出口の 堆積土砂）認められ，ま たTo-Cu灭山灰に覆われ る土石流堆積物の礫径に 上下流方向で差異が確認

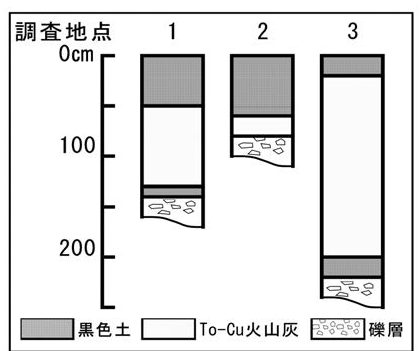

図-11 完新世の土石流堆積物 の露頭柱状図

Fig. 11 Exposures of the Holocene debris flow deposits
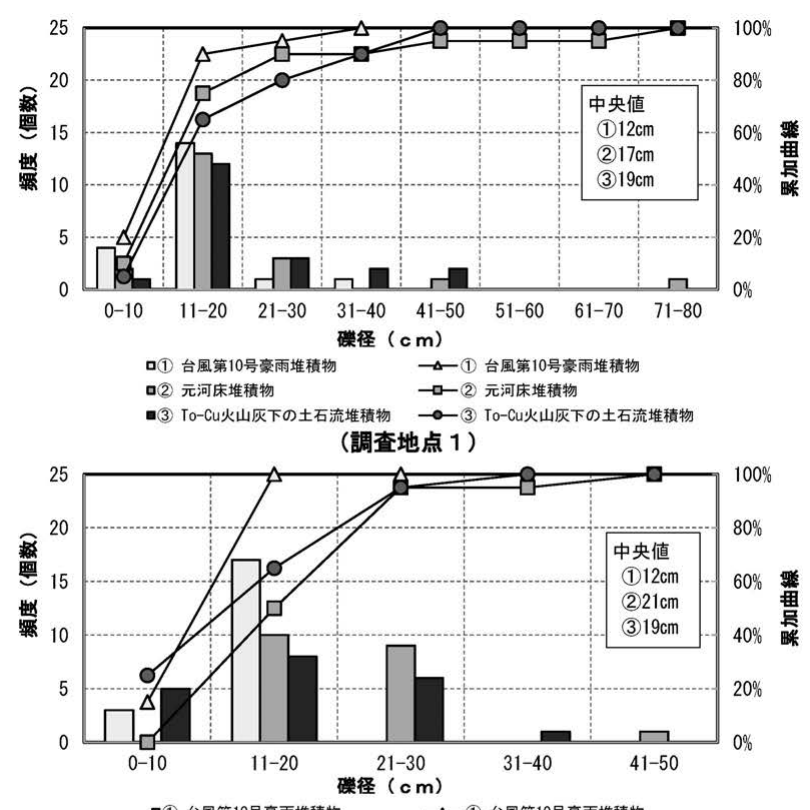

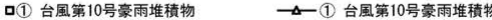

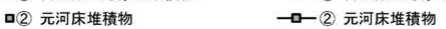

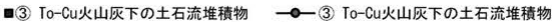

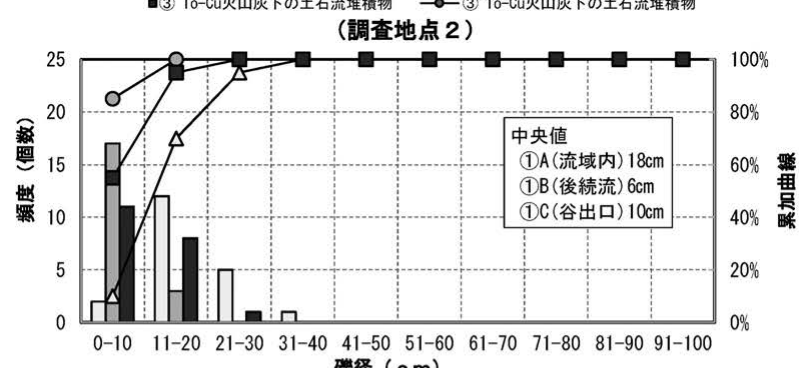

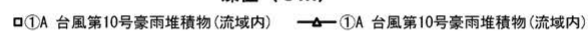
口1 18 台風第10号豪雨堆積物 (後続流) - - - 1 B 台風第 10 号豪雨堆積物 (後続流) - (1) 台風第10号豪雨堆積物 (谷出口) - - (1) C 台風第10号豪雨堆積物 (谷出口)

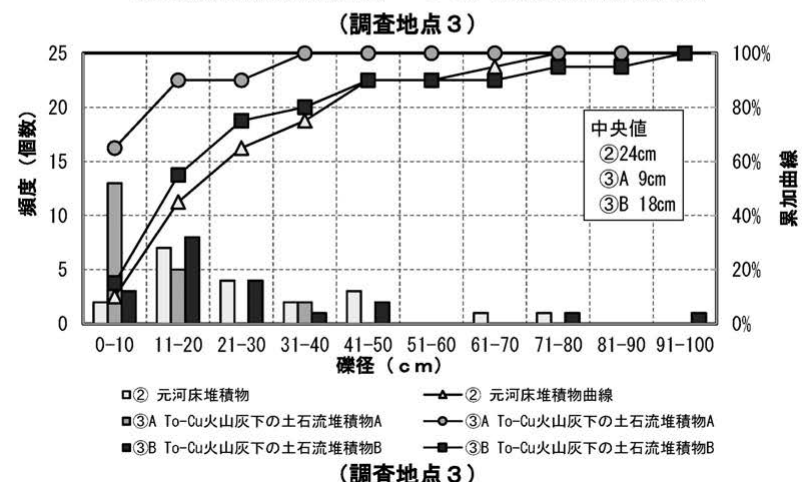
（調査地点 3 )

\section{図-12 礫径の粒度分布}

Fig. 12 Gravel size distribution

できたため，それぞれ砂径を計測した。ここで，台風第 10号豪雨による流出土砂が堆積した河床よりもやや深い 河床において碟径や形状が異なる堆積物を台風第10号豪 雨より前の河床堆積物と判断し，礫径を計測した。

調査地点 1 に扔ける台風第10号豪雨による土砂は，带 角砂〜亜円砂で礫径 $20 \mathrm{~cm}$ 以下が約 9 割を占める。一方, 元河床堆積物及びTo-Cu火山灰下の砂砂層も亜角礫〜亜 円砂主体ではあるが，礫径 $20 \mathrm{~cm}$ 以下は約 7 割であり， それより大きい鿬を混在する。

調査地点 2 における台風第10号豪雨による土砂は，带 
角磁〜角磁の碟径 $20 \mathrm{~cm}$ 以下の碟で構成されるのに対し, 元河床堆積物及びTo-Cu火山灰下の土石流堆積物は亜角 礫〜亜円礫主体ではあるが，礫径 $20 \mathrm{~cm}$ 以下は約 6 割で あり，それより大きい礫を混在する。

調査地点 3 では，台風第10号豪雨による流出土砂は, 総じて $20 \mathrm{~cm}$ 以下の礫が大半を占め, 土石流堆を含めて も $40 \mathrm{~cm}$ 以下の構成となっている。これに対して元河床 堆積物と $\mathrm{To}-\mathrm{Cu}$ 火山灰に覆われる土石流堆積物Bは, 2 倍 以上の径の䃌も確認された。To-Cu火山灰に覆われる土 石流堆積物 $\mathrm{A}$ は, 土石流堆積物Bのやや上流側に位置し, 土石流堆積物 $\mathrm{B}$ の後続流である可能性がある。また台風 第10号豪雨の堆積土砂に近い頻度分布を示すことから， 今回と同規模の土砂移動で堆積した可能性がある。

図ー13には，堆積物の種類ごとに礫径の特徵を示す。 横軸の番号は「調査地点一堆積物の種類」を表し, 調査 地点は図 - 10の $1 \sim 3$, 堆積物の種類は前述した(1)〜 (3), アルファベットに対応する。最小・最大值の差や標準偏 差をみると，台風第10号豪雨による流出土砂は淘汰が良 く，これ以外は淘汰が悪い傾向がある。

\section{3 完新世の土砂生産・移動についての考察}

5.2 で示したように，S-1段丘に相当する段丘を構 成する堆積物は, 層状堆積ではなく, 大礫を含む大小様々 な石礫が混在し，粘土質マトリクス亜角礫が多いことか ら，土石流形態または土石流形態のプロセスによる移 動・堆積と推定される。

土砂移動規模を堆積土砂の礫径からみると，台風第 10 号豪雨による流出土砂，それ以前の渓床堆積土砂，土石 流段丘では，台風第10号豪雨による流出土砂が相対的に 小さい鿬を主体とした土砂移動であった。また崩壊より も渓床・渓岸物質の二次移動が主体であった。一方，台 風第10号より前の渓床堆積土砂や土石流段丘の礫径は50 〜100cmを有しており，この点から台風第10号豪雨に比 べて規模の大きい土砂移動が生じたものと考えられる。 土石流段丘の形成時期は，約 $5,000 \sim 5,500$ 年前の $\mathrm{To}-\mathrm{Cu}$ 火山灰が堆積物を覆い，約 10,000〜12,000円前の分褐色 風化火山灰に覆われていない状況から完新世前期と考え られる。分褐色風化火山灰層下の斜面堆積物は一般に小

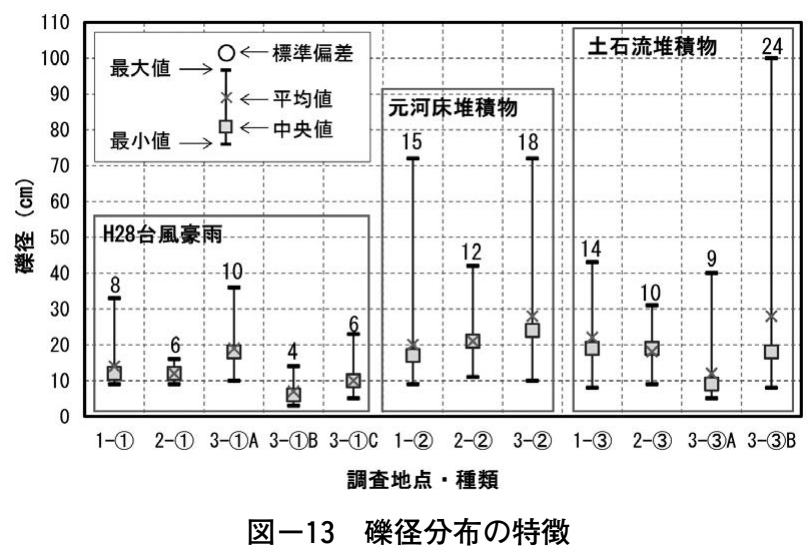

Fig. 13 Properties of gravel size distribution
鿬が多く，その時期に対応・形成した本川沿いの地形も 大礫を含まないとの報告 ${ }^{9}$ もあることから，最終水期の 土砂生産では大礫の割合が少なかった可能性がある。し たがって土石流として運搬された土砂の生産時期は，最 終水期終了後, $\mathrm{To}-\mathrm{Cu}$ 火山灰降下前の完新世前期と推定

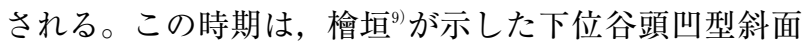
の形成時期に相当する。

\section{6. 北上山地における台風第10号豪雨による土砂生産・ 移動の地形的背景}

以上の検討結果を踏まえ，台風第 10 号豪雨，完新世の 土砂生産・移動を地形的背景からまとめると図－14のよ うに考えられる。

平成28年台風第10号豪雨による崩壊は，崩壊発生率の 高い地形要素でみると「下位谷頭凹型斜面とそれに連な る遷急線下方斜面」,「埋積谷」, 水期起源の斜面を含む 「その他の斜面」が該当した。崩壊により生産された土 砂は，渓床堆積土砂の侵食も合わせ，主に土砂流として 移動し，下流域で災害を生じさせたと考えられる。台風 第10号豪雨による崩壊が，地形発達に果たした主な役割 として遷急線の後退や集水地形の拡大が挙げられるが, 「下位谷頭凹型斜面」を新たに作るような大きな地形変 化を伴う土砂生産規模にはなっていない。

一方，当該地域の地形的背景に着目すると，最終水期 後半の凍結融解で生産された小礫が，ソリフラクション

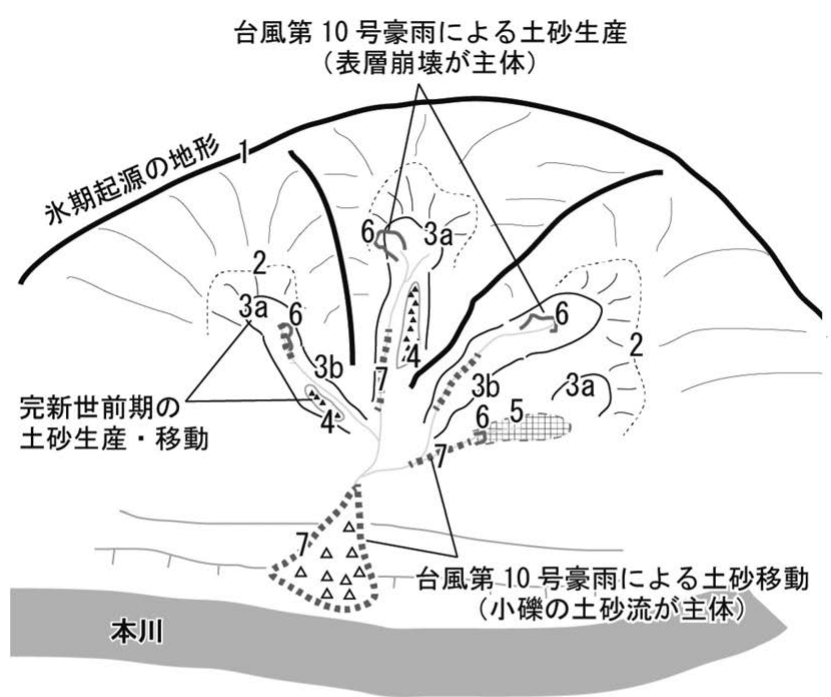

1 : 山頂緩斜面 - 平滑尾根型斜面 ${ }^{9)}, 2$ : 上位谷頭凹型 斜面 ${ }^{9)}, 3$ : 下位谷頭凹型斜面及びそれに連なる遷急線 下方斜面（3 a : 下位谷頭凹型斜面, $3 \mathrm{~b}$ ：連なる遷急 線下方斜面），4：支川の土石流段丘（本川の S-1 段丘 に連続）, 5 : 埋積谷, 6 : 台風第 10 号豪雨による崩壊,

7 : 台風第 10 豪雨による土砂移動

図一14 台風10号豪雨による土砂生産・移動とその地形的背 景の概念図

Fig. 14 Schematic diagram of the geomorphological background of the Kitakami Mountains and the sediment movement by the Typhoon Lionrock 
を主とする斜面物質移動により平滑でなだらかな斜面を 作るとともに上位谷頭凹型斜面を形成した ${ }^{9}$ 。完新世に 入り，斜面の開析が同時に進んだ同山地において，支川 では主に崩壊が「下位谷頭凹型斜面」を形成した。土石 流段丘を形成した時期を踏まえると，土石流として移動 した土砂の一部は「下位谷頭凹型斜面」形成時の崩壊土 砂が対応するものと推察される。土石流の一部は河川の 下刻・離水によって「土石流段丘」化し，段丘面にTo$\mathrm{Cu}$ 火山灰（約5500年前降下）を載せ，本川のS - 1 段丘 に対比できる段丘面として残存している可能性がある。 このような完新世における崩壊は，現在まで断続的に発 生し $\left(\right.$ たとえば田村 $\left.{ }^{37}\right)$ ，これにより下位谷頭凹型斜面 に連なる遷急線下の渓岸斜面（本論での下位谷頭凹型斜 面に連なる下方斜面）が形成されたと考えられる。

\section{7. おわりに}

平成 28 年 8 月の台風第 10 号豪雨により北上山地では 300 年超過確率を超える雨量により多数の土砂流出が生 じた。同豪雨による土砂生産・移動について，北上山地 の地形的背景に着目して検討した。

その結果，次のような知見が得られた。

(1) 現地調査と赤色立体地図を用いた地形判読結果から, 台風第10号豪雨による崩壊は「下位谷頭凹型斜面及 びそれら連なる遷急線下方斜面」，「埋積谷」，「その 他の斜面」において多く発生した。崩壊深 $1 \mathrm{~m}$ 程度 の表層崩壊が多数を占め，今回の土砂生産では，下 位谷頭凹型斜面を作るような大きな地形変化をさせ るまで至らなかった。

(2) 支川・支渓において，To-Cu火山灰に覆われ，完新 世前期に形成されたと推定される大礫を含んだ「土 石流段丘」が認められた。土石流段丘を構成する礫 は台風第10号の土砂移動の碟に比べて 2 倍以上大き いものもあり，台風第10号豪雨による土砂移動規模 に比べて大きい現象が完新世前期に発生したと考え られ，この土砂の一部は「下位谷頭凹型斜面」形成 時の崩壊起源である可能性がある。

台風第10号豪雨による土砂生産は, 地形発達から見る と大きな地形変化を伴わない現象であったと言える。し かし，北上山地の完新世における地形的背景からみると 今回以上の土砂生産・移動が過去に生じていることが古 い土石流堆積物の分布から推定された。また現状では侵 食が及んでいない「その他の斜面」が広く分布し，完新 世の地形発達を踏まえた土砂生産・移動現象を考慮する と，今後，規模の大きい土砂生産，これに伴う移動現象 の発生も想定される。この点で，本地域における土砂桨 害警戒避難体制を構築する上では，台風第10号豪雨によ る土砂生産・移動現象だけではなく，本論から推察され る過去の現象も注視すべき重要な情報と言える。

\section{謝辞}

岩手大学農学部の井良沢道也教授，弘前大学農学生命 科学部の鄒青穎助教には現地調査への同行, 調査結果の 考察にあたり助言をいただきました。岩手県県土整備部 河川課には航空レーザ計測データを提供いただき，計測 機関のアジア航測 (株)には同データの変換でお世話にな りました。最後に匿名の査読者 2 名からの有益な助言に より内容を改善できました。

ここに記して深謝申し上げます。

本論の一部は, 2018年度東北地理学会秋季学術大会に おいて「岩手県北上山地の小本川・閉伊川支川の土石流 段丘からみた完新世前期の土砂移動」と題して発表した。

\section{引用文献}

1）国土交通省（2017）：平成29年に発生した土砂災害，http：// www.mlit.go.jp/river/sabo/jirei/h29dosha/H29 dosyasaigai.pdf（参照日2018年 7 月14日）。

2 ) 盛岡地方気象台 (2016): 岩手県災害時気象資料 平成28年台 風第10号による大雨と暴風, 波浪（平成28年 8 月 29 日～31日）, 平成 28 年 9 月 2 日, $26 \mathrm{p}$.

3 ) 国立研究開発法人土木研究所水災害研究グループ (2016) : 平 成 28 年 8 月台風10号豪雨による岩手県小本川洪水災害調査報 告，土木研究所資料，第4384号, 80p.

4 ）国土交通省砂防部（2016）：台風第10号による土砂災害発生状 況, http : //www.mlit.go.jp/river/sabo/jirei/h28 dosha/161003\%20900_taifuu10gouniyorudosyasaigai.p（参 照 日2018年 7 月14日).

5 ）大河原正文 (2016）：台風10号により岩泉町で発生した地盤災 害の調查速報，平成 28 年台風10号災害緊急調查報告会，平成 28 年10月15日，岩手大学地域防災研究センター。

6 ）国土地理院（2016）: 平成28年台風第10号に関する情報，平成 28 年台風第10号 小本川 (岩手県岩泉町) ( $9 / 7$ 撮影), http : / /www.gsi.go.jp/BOUSAI/H28.taihuu10gou.html（参照日2018 年 7 月14日).

7 ）井良沢道也 - 檜垣大助 - 小岩直人 - 高橋未央 $\cdot$ 岡本隆 $\cdot$ 安野 雅満・多田信之・中島達也・新井瑞穂・落合達也・笠原亮 一 ·齋藤彰朗・佐藤聡・広瀬伸二・講武学・佐藤達也 ·大坪 俊介・真壁さくら（2017）：2016年 8 月30日台風10号による 岩手県岩泉町及び宮古市に扔ける土砂災害, 砂防学会誌, Vol. 69, No. 6, pp. 71-79.

8 ）岡本隆・阿部俊夫 - 大丸裕武 - 岡田康彦 (2017)：平成28年台 風第10号豪雨により岩手県内で発生した土砂災害の要因に関 する検討，東北森林科学会誌，vol. 22, No. 2, pp. 43-48.

9 ) 檜垣大助（1987）：北上山地中部の斜面物質移動期と斜面形成, 第四紀研究, vol. 26, No. 1, pp. 27-45.

10）大石道夫（2014）：微地形砂防の実際：微地形判読から砂防計 画まで，鹿島出版会, $287 \mathrm{p}$.

11）坂井佑介・木下篤彦・柏原佳明・梶原あずさ・小川紀一朗 （2012）：航空レーザ計測デー夕を用いた流木発生筒所の特徵, 砂防学会誌, vol. 65 , No. 3, pp. $47-51$.

12）アジア航測株式会社（2017）：赤色立体地図RRIM10_2016, https : //www.rrim.jp/ (参照日2018年 8 月12日).

13）金俊之・檜垣大助（2017）：市町村へのアンケート結果からみ た防災部局の土砂災害警戒避難体制の実態と課題について, 砂防学会誌, Vol. 70, No. 4, pp. 18-25.

14）田村俊和（1997）：なだらかな山地の形成とそこでの暮らしー 北上山地と阿武隈山地一日本の自然，地域編 2 東北（小島圭 二・田村俊和・菊池多賀夫・境田清隆編), pp. $72-91$.

15）川村寿郎 - 内野隆之 · 川村信人 · 吉田孝紀 - 中川満 - 永田秀 尚 (2013)：早池峰山地域の地質, 地域地質研究報告 (5 万分 
の 1 地質図幅), 地質調査総合センター, 101p.

16）国土交通省国土政策局国土情報課：国土数值情報(統一フォー マット $(\mathrm{SHP} \cdot \mathrm{GML}))$ 谷密度メッシュデータ.

17）鈴木隆介（1997～2000）：建設技術者のための地形図読図入門 $1 \sim 3$ 巻（第 3 章，第11章，第13章，第14章，第15章，第 17章), 古今書院, 942p.

18）吉田尚・大沢あつし・片田正人・中井順二（1984）：20万分 の 1 地質図幅 盛岡, 産業技術総合研究所地質調査総合セン ター.

19）滝澤雅之・井良沢道也・菊地克典・新井瑞穂・落合達也・中 島達也・(公社)砂防学会東北支部台風10号による土砂災害緊 急調査団（2017）：2016年台風10号による土砂災害における土 砂流出の実態, 第66回平成29年度砂防学会研究発表会概要集, pp. $700-701$.

20）渡辺智 - 鈴木篤 - 山下久美子 - 高橋研二 - 宇野沢剛（2017）： 2016年 8 月台風10号により発生した岩手岩泉地区土砂災害の 特徵, 第66回平成29年度砂防学会研究発表会概要集, pp. 702 -703 .

21）岩手県県土整備部河川課：2016年災害後計測の航空レーザ計 測データ及び赤色立体地図 (未公表).

22）国立研究開発法人土木研究所土砂管理研究グループ火山・土 石流チーム（2016）：深層崩壊の発生する恐れのある斜面抽出 技術手法及びリスク評価手法に関する研究 平成 28 年 3 月, 土木研究所資料, 第 4333 号, 参考資料 2 , pp. 参考 1 - 参考 37 .

23）高山陶子・濱田耕平・花井健太・織田和夫 - 角田里美 (2018)：ディープラーニングと赤色立体地図を用いた微地形 自動判読手法の検討, 第67回平成30年度砂防学会研究発表会 概要集, pp. 697-698.

24）田村俊和（1996）：微地形分類と地形発達一谷頭部斜面を中心 に一，水文地形学（恩田裕一 - 奥西一夫 - 飯田智之 ·辻村真 貴編), 古今書院, pp. 177-189.
25）大石道夫（1985）：目でみる山地防災のための微地形判読，鹿 島出版会, $267 \mathrm{p}$.

26）羽田野誠一 (1974)：崩壊性地形（その 1 ),（最近の地形学 8 )。 土と基礎, vol. 22, No. 9, pp. $77-84$.

27）羽田野誠一 (1974)：崩壊性地形 (その 2 ), (最近の地形学 8 )。 土と基礎, vol. 22, No. 11, pp. $85-93$.

28）羽田野誠一 (1979）：後水期開析地形分類図の作成と地くずれ 発生筒所の予察法，第28回昭和54年度砂防学会研究発表会要 旨集, pp. $16-17$.

29）大上和良・土井宣夫（1978）：北部北上低地帯の鮮新－更新両 統の層序について, 岩手大学工学部研究報告, 31, pp. 63-79.

30) Higaki, D (1992) : History of Morphogenetic Environments of the Kitakami Mountains, Northeast Japan,in the Last Quaternary,The science reports of the Tohoku University. 7 th series, Geography,vol. 42, No. 2, pp. 129-162.

31）早田勉・八木浩司（1991）: 東北地方の第四紀テフラ研究，第 四紀研究, vol. 30, No5, pp. 369-378.

32）町田洋・新井房夫 - 小田静夫 - 遠藤邦彦・杉原重夫（1984）: テフラと日本考古学－考古学研究と関係するテフラのカタロ グー, 古文化財編集委員会編「古文化財に関する保存科学と 人文・自然科学 $\rfloor, p p .865-928$.

33）菊池強一 ・檜垣大助・吉永秀一郎 (1981)：北上山地東部に分 布する縄文前期火山灰層について, 1980年東北地理学会学術大 会発表要旨, 東北地理, vol. 33 , No, 57 , pp. $57-58$.

34）岩泉町（1971）: 教育委員会竜泉洞新洞遺跡発掘調査報告, 岩 手県岩泉町文化財調查報告，第 2 集，pp. 1-80。

35）町田洋（1977）：火山灰は語る，蒼樹書房, 324p.

36）建設省河川局砂防部砂防課（1999）：土石流危険溪流および土 石流危険区域調查要領（案)，平成11年 4 月，p. 17 .

37）田村俊和（2004）：気候地形発達史研究における「斜面不安定 期」の概念，季刊地理学，Vol. 56, No. 2, pp. 67-80. (原稿受付2018年 9 月18日，原稿受理2019年 3 月 8 日) 